\title{
Contributions of Tourism to Community Development
}

\author{
Mbagwu, Felicia. $\mathrm{O}^{1}$, Bessong, Columbus. Deku² \& Anozie, Okechukwu. $\mathrm{O}^{3}$ \\ ${ }^{1}$ Department of Adult Education and Extra-Mura Studies, University of Nigeria, Nsukka, Nigeria \\ ${ }^{2}$ Department of Adult and Continuing Education, University of Calabar, Calarbar \\ ${ }^{3}$ Humanistic Unit School of General Studies, University of Nigeria, Nsukka, Nigeria \\ Correspondence: Mbagwu, Felicia. O, Department of Adult Education, University of Nigeria, Nsukka, Nigeria. \\ Tel: 234-803-794-8452. E-mail: fellymbagwu@yahoo.com
}

Received: June 6, 2016

doi:10.5539/res.v8n4p121

\author{
Accepted: July 14, 2016 \\ Online Published: November 15, 2016
}

URL: http://dx.doi.org/10.5539/res.v8n4p121

\begin{abstract}
This study focused on contributions of tourism to community development in Cross River State, Nigeria. Two research questions and two null hypotheses guided the study. The study adopted descriptive survey research design. The population used for the study was 357 respondents comprising, 101 community leaders and 256 tourism staff. A 21-item questionnaire and focus group discussion guide were used to elicit information from respondents and discussants. The questionnaire was analyzed using mean and standard deviation, t-test statistics was used to test the null hypotheses at 0.05 level of significance and the FGD was analyzed qualitatively. Findings from the study revealed among others, that tourism attracted banking institutions and communication industries; thus contributed to a high extent in economic development and very high extent in social development of Cross River State, Nigeria. Some recommendation was made based on the research findings.
\end{abstract}

Keywords: tourism, development, community development

\section{Introduction}

Tourism is one of the leading and lucrative industries in the world today that serves as a source of income generation. As one of the fastest growing industry in the world, its recreational activity contributes to a better understanding of places, people and their cultures. According to Omeje (2006), tourism is a social phenomenon which is likened to the art or practice of travelling temporarily out of one's place of abode. Likewise, United Nations World Tourism Organization (UNWTO, 2008) stated that tourism is a social, cultural and economic phenomenon which entails the movement of people to countries or places for personal or business purposes.

For Akam and Bassey (2014), tourism is influenced by tourism potentials which are those extraordinary natural, cultural, art and other resources in a particular place, or country serving as attraction, interesting and appealing to the sight and auditory organs of human beings. Tourism, they say, lies in the beauty of nature and man-made tourism potentials which indeed are endless, as it is instinctive to human beings to appreciate the nature like landscape, lakes, mountains or hills, rivers, rocks, waterfalls, caves, monoliths, wildlife, among others. Man-made tourism potential includes extraordinary art and architectural works, museum materials, archeological and cultural sites (Akam \& Bassey, 2014). Thus, natural scenery, favorable weather, climate and cultural heritage of these tourist centers attract dividends for the development of host communities where tourist sites are located. According to Agcas (2013), tourism has been identified globally as a very potent instrument for executing meaningful community development projects such as poverty alleviation initiatives and rural emancipation due to its numerous economic benefits such as the huge money realized from tourism activities. Tourism activities include, entertainment and recreational site, travel agencies, hotels, car rentals and others. Omeje (2006) noted that the Gross Domestic Product-GDP from tourism has been argued to be above that of the petroleum sector because it was observed that about 11 percent of World Gross Domestic Product (GDP) and about 10 percent of global employment of 212 million people world-wide and its total turnover volume is around US\$3.4 billion, which represents $5.5 \%$ of the global GNP. Nations received about 154 million tourist arrivals, which represents approximately $25 \%$ of the international travel traffic and about $24 \%$ or US\$109 billion, of the total hard currency income. There may have been marked improvement over the years. The International Monetary Fund (IMF), an arm of the World Bank has identified with the World Tourism Organization providing 
assistance in poverty alleviation in rural-urban migration, provision of social amenities and infrastructural facilities (Omeje, 2006).

Despite the attractiveness of tourism sites in Cross River State, it seems the potentials have not been adequately harmonized neither is there any adequate attention given to it in order to utilize and maximize these potentials for adequate development of the host communities. Tolu and Abe (2011) posited that Development is critical and essential to the sustenance and growth of any nation and that a community, region and even country can be classified as developed when it is able to provide qualitative life for her citizenry. The development of an area for tourist not only involves building of hotels and leisure facilities but also create a need to improve existing public and local amenities as well as creating new opportunities for the local communities. Although, there are many undermining factors that characterized most underdeveloped areas, such as insecurity and poor communication network. Epileptic power supply, high rate of unemployment, lack of indigenous industries, deplorable road network, frequent communal clashes, lukewarm attitude of some community leaders and lack of political will seem to have contributed to a large extent to low patronage in the tourism sites hinterland, hence, development of the host communities seem to be hampered. Community leaders are constitutionally elected members of a given community as agents of change. They are the key players in any community development process. It is their responsibility to harness both human and material resources in their community for development process. They are expected to be working closely with tourism staff, faith-based organizations and other community development agencies. Hence, they are recognized as those who are familiar with the culture of the people, and as such qualifies to represent their subjects, motivate and mobilize them to effectively participate in decision-making process for positive improvement in their living conditions. From a different synthesis, Anyanwu (2002) noted that most community leaders are only interested in power sharing and creation of positions instead of solving community problems. Lamenting, he maintained that most community leaders are known for diverting community funds into their pockets for developing estates in state capitals. This may be the reason why most communities in developing countries, like Nigeria, develop at a snail pace.

Understandably, community refers to a group of people living in a defined geographical location, sharing common interest and aspiration and working together to achieve common goals. Such people according to Ogonna (2007), share common geographical location which is normally a village or village group, common cultural traits, traditional affinity and working together to bring about social, economic and political development of the people. Hence, the process of bringing about improvement in people's living condition can only be achieved through the efforts of the people engaging in economic activities that would bring about continuous change in their present situations. Implying that economic growth must be constantly nourished by the fruits of human development such as improvements in people's skills and knowledge coupled with opportunities for their efficient use: better jobs and better conditions for new businesses to grow. Akam and Bassey (2014) affirmed that development is an aspect of progression, increase, improvement and advancement in every aspect of any community or country.

Community Development (CD) has been viewed by different authors based on their perception, hence it has remained a contested phenomenon which combines the idea of "community" with "development". The commonality in the conceptualization of CD by the authors reviewed is that they all point towards, impacting positively to the lives of a people in a given community through job creation, infrastructural development, empowerment, health, arts education, cultural, religious, technological, political, social and economic growth of the people. For example, Afuye (2005) conceptualized community development as a structured intervention that gives communities greater control over the conditions that affect their lives. Providing further support, Eze-Uzomaka (2006) takes CD to mean people in the community engaging in a process aimed at improving themselves in education, self-employment, healthcare delivery, agriculture, social infrastructure and environmental conditions among others.

From the foregoing, community development could be operationally defined as positive changes in socio-cultural, socio-economic and political settings of a giving geographical area which could be accessed through the innovations and advancement emanating from the above changes. In this regard, for effective community development to take place through tourism, the people in the community must also contribute their individual and collective efforts to benefit from the dividends of tourism in their community. The people must be friendly, hospitable, and cooperative ensure there is peace in the community. Moreover, tourism destinations, hospitality industries and activities therein must be attractive and accessible with basic facilities to attract income from both local and international tourists. The process of making any tourism site attractive and accessible can lead to community development. Therefore, in ascertaining tourism contributions to community development 
there is need to focus on the economic and social well-being of the society and particularly the host communities.

\section{Economic Contribution of Tourism to Community Development}

Tourism has been adjudged to have lofty economic benefits to societies. It is worthy to note that the economic contribution of tourism lies in the purchasing power generated from revenues through the expenditure of visitors (Ghosh, 2011). For example, international tourists in their turn spend trillions of dollars in the host countries visited during their travel, resulting in great increase in a wide range of economic activity which, according to WTO (2011), provides a major contribution to foreign exchange earnings of several developing and even developed countries for the development of communities; providing the people with local employment, basic amenities, educational opportunities and infrastructural facilities in order to improve their well-being. Its importance in the economic development of countries made economists to call it an invisible exports which triggers off both economic and social transformation. For example in Nigeria, the economic impact of tourism on her national economy is estimated at US\$280 million or N36 billion. Downstream economic impact from the "export" revenues of international tourist spending are estimated to generate additional gross revenue of US\$ 224 million or N29 billion (Abubakar, 2014). Literature shows that tourism is one of the most profitable businesses in the world, now considered the leading industry in many parts of the world. The economic contribution of tourism now is great and cannot be underestimated in many countries due to its faster growth than other sectors of the economy (Fotuhinia, Toranol, \& Mazidi, 2014). Tourism acts as catalyst for growth of trade and industry and increase in self employment opportunities like establishing restaurant, kiosk, and cyber café which can facilitate livelihood fast more than formal employment (Ijeoma, 2010).

\section{Social Contribution of Tourism to Community Development}

In the era of globalization, the social contribution of tourism to community development cannot be ignored by country, state, community and individuals with positive idea for development as Ezeani (2015) clearly stated that today, no country of the world can afford to ignore the importance of tourism to its economic, social and cultural development. More than before, nations and group of nations have become increasingly more aware of the immense social benefits derivable from tourism. Evidence from the words of Bhatia (2007) was that tourism become a popular global leisure activity. An unique industry without smoke, an educational institution without classroom, integration without legislation, and diplomacy without formality. More importantly, social interaction between tourists and host communities enhances the mutual appreciation, tolerance, understanding, awareness, family bonding, learning, respect and likings. It is equally established that residents of the host country or state get enrich with information about the outside world, may also enjoy facilities such as schools, libraries, healthcare institutions, and internet facilities provided by tourism industry (Sharma, Kukreja, \& Sharma, 2012).

Further, tourism has been recognized as a basic and desirable human activity which can contribute to investment in arts and culture, and establishment of a new international economic order that will help to eliminate the widening economic gap between development and progress, particularly in developing countries. However, as there are social benefits of tourism, so also there may be the negative social impacts which cannot be ignored even though not within the scope of this present study. It worth mentioning here that there may be change or loss of the people's indigenous identity and values, culture clashes, increase in crime, increase in cost of living, demand for resources and ethical issues bothering on increase in sex tourism or the exploitation of child workers within the host communities.

\section{Statement of the Problem}

Generally, tourism has been adjudged a potent sector for generating income and promoting community development. Despite the enormous potentials and contributions of tourism industry to development worldwide due to the huge revenue accruing from the industry, it seems the impact has not been substantially felt in terms of development in the host communities in Cross River State, Nigeria. For example, pilot study by the researchers revealed the presence of serious chains of potholes and dilapidated roads network leading to the host communities housing the giant tourist industries. Also, there are visible poverty, high rate unemployment and unkempt environment among others. It is sad to note that attention has not been adequately given to development of these host communities; in terms of construction of good roads, provision of portable water, good public schools, rural electrification, construction of markets and entrepreneurial skills acquisition training centers where people could learn and acquire saleable skills in order not to depend so much on government for development package that may not be forth coming or seeking for white collar jobs which are grossly inadequate or engaging in militant activities. 


\section{Purpose of the Study}

Consequently, the study generally focused on the contributions of tourism to community development in Cross River State, Nigeria. Specifically, the study sought to:

(1) Ascertain the extent to which tourism has contributed to the economic development of Cross River State.

(2) Ascertain the extent to which tourism has contributed to the social development of Cross River State.

\section{Research Questions}

This study will be guided by the following research questions:

(1)To what extent has tourism contributed to the economic development of Cross River State?

(2)To what extent has tourism contributed to the social development of Cross River State?

Hypotheses:

The following null hypotheses were tested at 0.05 level of significance.

$\mathrm{HO}_{1}$ : There is no significant difference between the mean ratings of community leaders and tourism staff on the extent to which tourism has contributed to the economic development of Cross River State.

$\mathrm{HO}_{2}$ : There is no significant difference between the mean ratings of community leaders and tourism staff on the extent to which tourism has contributed to the social development of Cross River State.

\section{Review of Related Studies}

Achugbu (2011) carried out a research on, the role of hospitality in tourism development: A Case Study of Selected Hotel Establishment in Awka, Anambra State. The study examined the role of hotels in tourism promotion, examined the security issues as it affects hotel operations and examined the quality of service rendered to customers in these hotels, as well as providing a guide to the numerous hospitality business in Anambra State.

The study used qualitative research method, as well as eliciting information from primary and secondary sources. The population consisted 200 hotel managers. The instrument for data collection was a structured questionnaire and interview. The data was analyzed qualitatively. From the findings of the study it was concluded that hospitality is an indispensable component of tourism and many countries and many world economics rely on their tourism industries. Also, findings further revealed that hospitality is one business that has provided jobs to different kinds of people, helped in beautifying the environment, promoting people's culture and fostering international relations. This study is related to the present study because both focused on tourism but differed in their scope. The earlier studies are specifically of economic, social and cultural development which is considered as prerequisites for community development which happened to be the focus of this present study.

Echeter (2011) carried out a study on developing cultural and historical tourism in Ohaji and Egbema local government Area, Imo State. The purpose of the research was to identify the potential, cultural and historical attraction of tourism and the impact in the study area. The study adopted ethnographic research method which is a natural way of inquiry, seeking in-depth understanding of a social phenomena within a natural setting. The population comprised 540 community leaders and tourism staff while the sample for the study was 140 respondents made up of both community leaders and tourism staffs. Findings from the study revealed that the major problems facing the communities and Nigeria at large is the over dependence in oil revenue and neglect of the development of tourism or investing on any other in-come generating sector. Based on the findings the study recommended among others that there should be national re-orientation on the diversification of the economy, significance of historical and cultural heritage of the people and the need to preserve them for the development of host communities.

Furthermore, Odum (2011) carried out a study on "Community Involvement in Tourism Planning and Development: A study of selected Tourism Attractions in Anambra State". Four research questions guided the study. The study adopted qualitative research methods. The population of the study was 600 community leaders and tourism staff. A simple random sampling technique was used to draw a sample size of 200 community leaders and tourism staff. Data were collected through primary and secondary sources. The data were analyzed using qualitative statistical tool. The study argued that tourism potentials are huge sources of income generation for the state government, and a means for rural development, that cultural, natural, man-made historic, archaeological, and ethnographic attractions exist in Anambra State in large numbers though most of them are underdeveloped. These studies reviewed are related to this present study because they focused on tourism and its 
relevance to people's economic, social and cultural development which are considered as prerequisites for community development which is the focus of this present study.

\section{Research Method}

Descriptive survey research design was adopted for this present study. According to Nworgu (2015), descriptive survey research design aims at collecting data on and describing in a systematic manner the characteristic features or facts about a given population. It is therefore, considered appropriate for this study because the researchers made use of data collected from the sample to ascertain the contributions of tourism to community development in Cross River State (CRS) Nigeria. In addition, a qualitative method of field survey in the form of Focus Group Discussions (FGD) guide was also adopted. Cohen and Manion (2007) stated that Focus Group Discussion is the gathering of a group of people in which their examine specific subject with a moderator who keeps the group to the subject under consideration. The FGD provides a two way communication, offers time for in-depth discussion, provides immediate feedback on new information, fosters group spirit when common concerns are identified and allow for emotional as well as intellectual reaction. Hence, the researchers used both quantitative and qualitative methods of field survey in this study. The study was conducted in CRS, Nigeria which has eighteen Local Government Areas. CRS is bounded on the North by Benue State, on the South by Akwa Ibom State, on the East by the Republic of Cameroun and on the West by Ebonyi and Abia States (Source: Government of Cross River State, 2015). The Area is preferred because of the endowed cultural heritage and enormous natural tourism sites. More so, the people of this area seem to depend so much on the income that is generated through tourism activities in their communities. A little proportion of the indigenes of the area are into public service and politics while majority are predominantly subsistence farmers, business men and women.

The population of this study was 5,458 respondents comprising 3,928 tourism staff and 1,530 community leaders in the three senatorial zones that make up Cross River State. Namely: Cross River Central, Cross River South and Cross River North (Source: Tourism bureau and department of chieftaincy affairs, Calabar, Cross River State, 2015). A sample of 357 respondents was used for this study. This sample size represented $6.54 \%$ of the entire population as recommended by Cohen, Manion and Morrison (2011) for a confidence level of $95 \%$ of the population.

A multi-stage sampling procedure was adopted for this study. It is sampling technique involving two or more stages of selection (Osuala, 2005). In the first stage, four local government areas (Boki, Etung, Obudu, \& Akamkpa) were selected from the three senatorial zones using simple random sampling technique with replacement. In the second stage, simple random sampling technique with replacement was also used to select 16 communities from the four local government areas, 4 from each local governments. In the third stage, proportionate sampling technique was used to sample 256 tourism staff in the 16 selected communities respectively. Proportionate sampling technique was used in the third stage because the numbers of tourism staff in each of the 16 sampled communities were not equal. The whole sampled community leaders numbering 101 were used making it a total of 357 respondents.

Two instruments used for data collection in this study is a structured questionnaire titled "Contributions of Tourism to Community Development Questionnaire" (CTCDQ) and a Focus Group Discussion (FGD) guide.

A 21-item questionnaire and FDG guide were developed by the researchers based on the research questions. The questionnaire consist of two clusters: A and B. Cluster A was used to elicit information on the extent to which tourism has improved economic development of CRS while cluster B determined the extent to which tourism has contributed to social development of CRS. The instrument was designed on a four-point rating scale with numerical response options in descending order of Very High Extent (VHE)-4 points, High Extent (HE)-3 points, Low Extent (LE)-2 points and Very Low Extent (VLE)-1 point.

The Focus Group Discussion (FGD) guide was used to elicit qualitative information from six community leaders and six tourism staff which were randomly selected from the communities not been used for this study.

The FGD schedule guide was based on the purposes and research questions guiding the study which the discussion moderator followed diligently. The FGD schedule was designed in two parts. Part A was an introductory letter written by the researcher to acquaint the discussants with the purpose of the discussion and to solicit their cooperation when sharing information on issues that were raised during the discussion. Part B of the Focus Group Discussion schedule was based on the two research questions. This section is made up of four open ended questions that were discussed, although other related questions were raised as the need arises.

To ensure the validity of the instruments (the quantitative and qualitative), the questionnaire and FGD guide were given to three experts to validate, two of the experts are from the Department of Adult Education and 
Extra-Mural Studies and the third is from Measurement and Evaluation unit of the Department of Science Education, all in the faculty of Education, University of Nigeria, Nsukka for critiquing and editing. The corrections and suggestions made by the experts guided the researchers in their final draft of the questionnaire and the Focused Group guide.

To test the reliability of the instrument, the researchers distributed 20 copies of the questionnaire to community leaders and tourism staff in Ibom Plaza, Uyo, Akwa-Ibom State which is not part of the study area. Data collected was subjected to internal consistency test using Crombach alpha procedure. This gave the reliability co-efficient value of .76 for cluster A, .64 and overall reliability of .70 which was an indication that the instrument was considered reliable.

The researchers made use of two field assistants who were briefed on the modalities for administering the instruments to the respondents. The data collected was analyzed using mean and standard deviation. The decision rule used on the mean was 2.50 . This means that any item with a mean score of 2.50 and above was considered important for the contributions of tourism to community development and as such accepted. While any mean score below 2.50 was considered negative and unimportant for the contributions of tourism to community development, and therefore was rejected. T-test statistics was used to test the three null hypotheses at 0.05 level of significance. Focused Group Discussion was transcribed and analyzed using qualitative analysis.

\section{Results and Discussion}

Table 1. Mean rating and standard deviation showing the extent tourism has contributed to the economic development of Cross River State

\begin{tabular}{|c|c|c|c|c|c|}
\hline $\mathbf{S} / \mathbf{N}$ & Item Statement & $\mathbf{N}$ & $\mathbf{X}$ & SD & Dec. \\
\hline 1 & $\begin{array}{l}\text { Tourism attracts banking institution which makes banking transaction easy and added } \\
\text { value to the economic activities in Cross River State. }\end{array}$ & 357 & 2.68 & 0.03 & High Extent \\
\hline 2 & $\begin{array}{l}\text { Tourism attracts communication industries which created business opportunities and } \\
\text { employment in Cross River State. }\end{array}$ & 357 & 2.72 & 0.99 & High Extent \\
\hline 3 & $\begin{array}{l}\text { Tourism increases transport network which makes movement of loads and people easy in } \\
\text { Cross River State. }\end{array}$ & 357 & 2.98 & 0.99 & High Extent \\
\hline 4 & $\begin{array}{l}\text { Tourism brings about construction of roads and bridges in Cross River State and makes } \\
\text { business transaction flow well. }\end{array}$ & 357 & 2.96 & 0.99 & High Extent \\
\hline 5 & $\begin{array}{l}\text { Tourism brings about expansion of the markets of the host communities in Cross River } \\
\text { State and thus causes increase production. }\end{array}$ & 357 & 2.99 & 0.06 & High Extent \\
\hline 6 & $\begin{array}{l}\text { The number of tourists that visit tourist sites in Cross River State increase economic } \\
\text { development of the host communities. }\end{array}$ & 357 & 2.85 & 0.06 & High Extent \\
\hline 7 & $\begin{array}{l}\text { Tourism brings an increase in the rate of buying and selling of goods and services to the } \\
\text { host communities in Cross River State. }\end{array}$ & 357 & 2.57 & 0.07 & High Extent \\
\hline 8 & $\begin{array}{l}\text { Tourism attracts foreign investors to Cross River State and thus encourages the business } \\
\text { growth of the host communities. }\end{array}$ & 357 & 3.04 & 1.23 & High Extent \\
\hline 9 & $\begin{array}{l}\text { Tourism brings about infrastructural development which boosts the economy of Cross } \\
\text { River State. }\end{array}$ & 357 & 2.65 & 0.67 & High Extent \\
\hline 10 & $\begin{array}{l}\text { Tourism increases the internally generated revenue for the development of the host } \\
\text { communities in Cross River State. }\end{array}$ & 357 & 2.55 & 0.88 & High Extent \\
\hline \multirow[t]{2}{*}{11} & $\begin{array}{l}\text { Tourism attracts industrialists for the establishments of companies and industries for } \\
\text { community development in Cross River State. }\end{array}$ & 357 & 2.55 & 0.88 & High Extent \\
\hline & Grand Mean & 357 & 2.77 & 0.63 & High Extent \\
\hline
\end{tabular}

Table 1 shows the mean and standard deviations of the extent tourism has contributed to the economic development of Cross River State. Result shows that all the responses of respondents on items 1-11 have mean ratings above the criterion level of 2.50 with their corresponding numerical values of standard deviations, and grand mean of 2.77 with SD of 0.63 . Since, the mean ratings are above the criterion level of 2.50 for accepting 
an item, this confirms that the respondents agreed to a high extent, that tourism has contributed to the economic development of Cross State.

Table 2. Mean rating and standard deviation showing the extent tourism has contributed to the social development in Cross River State

\begin{tabular}{|c|c|c|c|c|c|}
\hline $\mathbf{S} / \mathbf{N}$ & Item Statement & $\mathbf{N}$ & $\mathbf{X}$ & SD & Dec. \\
\hline 1 & $\begin{array}{l}\text { Tourism promotes peaceful coexistence among the people of the host communities } \\
\text { and strangers which is a hall mark for mutual and peaceful coexistence in Cross } \\
\text { River State. }\end{array}$ & 357 & 3.68 & 1.03 & Very High Extent \\
\hline 2 & $\begin{array}{l}\text { Tourism boosts recreational and sports activities which attract many tourists to the } \\
\text { host communities in Cross River State. }\end{array}$ & 357 & 3.72 & 1.78 & Very High Extent \\
\hline 3 & $\begin{array}{l}\text { Tourism promotes enlightenment, education in Cross River State which enhances } \\
\text { social development. }\end{array}$ & 357 & 3.98 & 1.98 & Very High Extent \\
\hline 4 & $\begin{array}{l}\text { Tourism now provides services such as training and skill acquisition programmes for } \\
\text { human resources development in Cross River State. }\end{array}$ & 357 & 3.96 & 1.99 & Very High Extent \\
\hline 5 & $\begin{array}{l}\text { Tourism brings people together across the globe which enhances mutual coexistence } \\
\text { among different races. }\end{array}$ & 357 & 3.99 & 1.57 & Very High Extent \\
\hline 6 & $\begin{array}{l}\text { Tourism brings many communities together in Cross River State for the promotion } \\
\text { of social creativity through carnival activities. }\end{array}$ & 357 & 3.85 & 1.93 & Very High Extent \\
\hline 7 & Tourism activities attract national and international goodwill in Cross River State. & 357 & 3.57 & 1.07 & Very High Extent \\
\hline 8 & $\begin{array}{l}\text { Tourism attracts the installation of internet facilities to the tourism sites which } \\
\text { enhance social networks connectivity for social interaction and developments among } \\
\text { the people of the area. }\end{array}$ & 357 & 3.04 & 1.53 & Very High Extent \\
\hline 9 & $\begin{array}{l}\text { Tourism activities increase the level of intimacy that prevails among the people of } \\
\text { the area and outside the tourism sites. }\end{array}$ & 357 & 3.50 & 1.77 & Very High Extent \\
\hline \multirow[t]{2}{*}{10} & Tourism promotes interpersonal relationships which facilitates social development. & 357 & 3.52 & 1.88 & Very High Extent \\
\hline & Grand Mean & 357 & 3.58 & 1.65 & Very High Extent \\
\hline
\end{tabular}

Table 2 shows the mean and standard deviations of the extent tourism contributed to the social development of Cross River State. Result shows that all responses of respondents on the items (1-10) have mean ratings above the criterion level of 2.50 respectively, with their corresponding standard deviations. Since, the means ratings are above the criterion level of 2.50 for accepting an item. This means that the respondents agreed to all the items. The grand mean of 3.58 with a standard deviation of 1.65 signify the very high extent tourism has contributed to social development of Cross River State.

Hypothesis one:

There is no significant difference between the mean ratings of community leaders and tourism staff on the extent to which tourism has contributed to the economic development of Cross River State.

Table 3. T-test analysis of the mean ratings of community leaders and tourism staff on the extent to which tourism has contributed to the economic development of Cross River State

\begin{tabular}{lllllll}
\hline Status & $\mathrm{N}$ & Mean & Std. & Df & t-cal & Sig. (2-tailed) \\
\hline Community Leaders & 101 & 3.21 & .28 & 355 & -.357 & .722 \\
Tourism Staff & 256 & 3.23 & .34 & & & \\
\hline
\end{tabular}

Table 3 shows the probability associated with the calculated value of $\mathrm{t}(-.357)$ at 335 degree of freedom for the mean difference between community leaders and tourism staff on the extent to which tourism has contributed to the economic development of Cross River State. Since the probability value of 0.722 is greater than 0.05 level of significance, the null hypothesis was accepted. Therefore, implying that there is no significant difference in the 
mean ratings of community leaders and tourism staff on the extent to which tourism has contributed to the economic development of Cross River State.

Table 4. T-test analysis of the mean ratings of community leaders and tourism staff on the extent to which tourism has contributed to the social development of Cross River State

\begin{tabular}{ccccccc}
\hline Status & $\mathrm{N}$ & Mean & Std. & Df & t-cal & Sig. (2-tailed) \\
\hline Community Leaders & 101 & 3.01 & .28 & 355 & -1.266 & .209 \\
Tourism Staff & 256 & 3.09 & .29 & & & \\
\hline
\end{tabular}

Table 4 shows the probability associated with the calculated value of $\mathrm{t}(-1.266)$ at 335 degree of freedom for the mean difference between community leaders and tourism staff on the extent to which tourism has contributed to the social development of Cross River State. Since the probability value of .209 is greater than the 0.05 level of significance, the null hypothesis was accepted. Thus, there is no significant difference between the mean ratings of community leaders and tourism staff on the extent to which tourism has contributed to the social development of Cross River State.

\section{Discussion of Findings}

From the results of this study, respondents agreed that tourism has contributed to the economic development of Cross River State. The result among others shows that tourism attracts banking institution, foreign investors and communication industries. This is in line with Ibumilua (2009) who noted that such economic investments brings about influx of people, job opportunities, increase in economic activities and improvement in transportation, thus, making buying and selling, movement of goods, services and people easy. It is equally believed that tourism will motivate the people to engage in various income generating activities, thus encouraging business growth of the host communities and Cross River State in general. This is in line with Eze-Uzomaka (2006) who posited that community development bring about change in an environment and enhanced livelihood of the people so that they can address their problems.

From the research findings, respondents subscribed to all the items that tourism has contributed to a very high extent in the social development of Cross River State. The results revealed among others that tourism, promotes peaceful coexistence among the people of the host communities and strangers, boost recreational and sports activities which attract many tourists to the host communities, promotes enlightenment, education and interpersonal relationships which facilitates social development among people. These findings are in line with Omeje (2006) which affirmed that tourism contributes to social and economic and cultural development of a country. Ghosh (2011) also stated that social interaction between tourist and host community enhance the mutual appreciation, tolerance, understanding, awareness, family bonding, learning, respect and likings which enhance social development in the host community. Moreso, the very high extent recorded against social development in CRS can be attributed to the tourist sites which has promoted and added color to Nigerian carnival festivals and cultural development in Cross River State, thereby improving the content of Nigerian tourism industry.

The results of hypotheses analyzed also indicated that there is no significant difference in the mean ratings of community leaders and tourism staff on the extent to which tourism has contributed to both the economic and social development of Cross River State. These findings are in line with Kizlik (2012), who made it clear that tourism is one of the fastest growing economic development of communities and their social transformation. In support of this, Futuhinia, Toranlo and Mazidi (2014) submits that the economic contribution of tourism now is great and cannot be underestimated. Tourism industry according to the authors, provide job opportunities thereby enhancing the economic sustainability of people.

The focus Group Discussion analysis also indicate that tourism: increases the internally generated revenue for the development of the host communities in Cross River State River State, created local employment opportunities for members of the communities, increases transport network which makes movement and transportation of goods easy. However, amidst the heat of the discussion, three of the discussants quipped that, much needs to be done in their communities by the government so that they will feel the desired impact of tourism in their lives. 


\section{Conclusion}

This study has revealed the economic and social significance of tourism and its multiplier effects on a country's economy for community development. The establishment of tourist facilities and infrastructural facilities like banking and communication industries in rural communities is a cost effective way of meeting national development objectives which focuses on the development of communities. Tourism attracts foreign investors and as such, the economic value of foreign exchange earnings from tourism contributes to government's revenue for the development of rural areas and community projects in order to ensure sustainable livelihood of the people. The findings also revealed that tourism is an effective tool for positive image making, offers good opportunity for personal contact and interchange of cultures and ideas; thus creating opportunities to seek cooperation, inter tribal peace, and tranquility; it is expected that these pre-requisites for community development are sustained.

\section{Recommendations}

Based on the findings of the study, the following recommendations are considered:

(1) The government should promote sustainable tourism development in order to ensure that the local communities, not only the state or federal government benefits from the financial dividends generated from tourism industry within their domain.

(2) The communities need a re-orientation on the need for them to know that their destinies are in their hands and should not rely on the government for solutions to all the problems in their community, rather they should combine their efforts and bring about change in any aspect of their lives requiring change. This is because community development is people-oriented, problem-solving and like democracy, it is of the people, by the people and for the people.

(3) There is need for communities to partner with faith-based and other Non-governmental organizations in their development initiatives so that they can provide the communities with basic amenities and infrastructural facilities so that more tours and more revenues would be realized. This is necessary too, since the government alone cannot foot development initiatives alone.

\section{References}

Abionu, C. O. (2002). The Impact of Globalization on Business Education. Education Journal.

Anyanwu, C. N. (2010). CE: The African Dimensions. Ibadan: Alfas, Nigerian Co.

Abubakar, I. Z. (2014). The Economic Contribution of Tourism in Nigeria and the Strategies for Increasing the Contribution in the Future. Retrieved from https://www.academic.edu/5936943/economic

Achugbu, C. (2011). The Role of Hospitality in Tourism Development: A Case Study of Selected Hotel Establishment in Awka, Anambra State (Unpublished M.A. Thesis). Department of Archaeology and Tourism, University of Nigeria, Nsukka.

Afuye, H. O. (2005). Community Development in West Africa. Ibadan: University Publishing Press.

Agcas, J. (2013). Tourism Officer. Retrieved from http://www.prospects.au.u

Akam, K. O., \& Bassey, G. (2014). The Role of Visual Arts and Theatrical Elements in Nigerian Carnival Dances: Veritable Means toward Tourism Development and National Integration. In National Conference of Dance Scholars Society of Nigerian (2nd ed.). University of Benin, Benin City, Nigeria.

Akpan, E. I. (2011). Globalization: The Opportunities and Threats to Banking Reforms in Nigeria. Nigerian Academy of Management Journal.

Andersson, T. D., \& Getz, D. (2009). Tourism as a Mixed Industry: Differences between Private, Public and Not-for-Profit Festivals. Tourism Management, 30(6), 847-856.

Bhatia, K. A. (2007). International Tourism Management. New Delhi: Sterling Publishers Private Limited.

Cohen, L. M., \& Morrison, K. (2007). Research Methods in Education (6th ed.). London: Rutledge.

Coyle, M. C. (2000). Tracking the Work: Building a Co-Ordinated Community Response: A Guide for Community. Oxford University Press.

Cunha, L. (2012), The Definition and scope of Tourism: A Necessary Inquiry. Retrieved from http://hdl.handle.net/10437/5239

Dupond, M. (2013). Factors Affecting the Development of the Tourism Industry. Retrieved January 14, 2015, from http://articles-junction.blosgspot.com/2013/07/five-main-factors-influencing-growth-of.html 
Echeta, S. O. (2011). Developing Cultural and Historical Tourism in Ohaji/Egbema Local Government Area, Imo State (Unpublished M.A Thesis). Department of Archeology and Tourism, U.N.N.

Ezeani, J. P. (2015). Impact of Tourism in Ezeagu Local Government area of Enugu State. Retrieved September 8, 2015, from http://www.enugustatetourismboard.com

Eze-Uzoamaka, P. I. (2006). Tourism and Coming in Nigeria. In P. U. Okpoko (Ed.), Issues in Tourism and Development. Nsukka: Afro-Orbis Publishing Co. Ltd.

Fotuhinia, A., Toranol, H. S., \& Mazidi, M. S. (2014). A Review on factors Effecting on Tourism Policy Implementation: A tool on the Development of the Tourism Industry in Islamic republic of Iran. Developing Country Studies, 4(22).

Ghosh, B. (2011). Tourism and Travel Management. Bengaluru: Vikas Publishing House Put Ltd.

Government of Cross River State (2015). A Brief History of Cross River State. Retrieved October 28, 2015, from http://www.Crossrivestate.gov.ng/briehistoryofcrossriverstate

Hall, C. M. (2000). Tourism Planning: Policies, Processes and Relationship. Harlow: Pearson Education Ltd.

Hills, M. (2011). What is Community Development. Retrieved September 8, 2015, from http://www.comdeu.com/auth/fan.htm

Ibimilua, A. F. (2009). Tourism Participation: Attractions, Influences and Key Trends in Ekiti State, Nigeria. Africa. Research review: An International Multi-Disciplinary Journal, 3(3).

Ijeoma, E. (2010). NTDC Has Contributed to the Nation's Economy-Runsewe. Tourism News Nigerian. $\begin{array}{llll}\text { Retrieved } \quad \text { February } & 23, & \text { from }\end{array}$ http://tourism-news-nigeria.blogspot.com/2010/10/ntdc-has-contributed-to-nations-economy.html

Kaise, S. (2012). Characteristics of the Tourism Industry. Retrieved October 23, 2015, from https://sebastiankaiser. Worldpress.com/2012/05/21/characteristics-of-the-tourism-industry/

Kizlik. (2014). Measurement, Assessment, and Evaluation in Education. Retrieved October 23, 2015, from http:/ww.adprima.com/measurement.htm

Kung, H. (2006). Tracing the way: Spiritual Dimensions of the World Religions. Continuum International Publishing Group.

Maxwell, G. N. (2010). Principles of Evaluation. Washington DC: national Academy Press.

McCarthy, K. (2013). The Importance of Tourism. Retrieved October 23, 2015, from https://commercialobserver.com/2013/09/the-importance-of-tourism/

Nworgu, B. G. (2015). Educational Research. In Basic Issues and Methodology (2nd ed.). Nsukka: University trust Publishers.

Odum, C. J. (2011). Community development in tourism planning and development: A case study of Selected Tourism Attraction in Anambra State (Unpublished M.A. Thesis). Department of Archaeology and Tourism, University of Nigeria, Nsukka.

Ogunna, C. E. A. (2007). Basic Issues in community Development and Local Government. Owerri,Versatile Publishers.

Omeje, P. U. (2006). Tourism and Development Corporation. In P. U. Okpoko (Ed.), Issues In Tourism Planning and Development. Nsukka: Afro-Orbis Publishing Co. Ltd.

Osuala, E. C. (2005). Introduction to Research Methodology. The Millennium edition, Cheston Books.

\section{Copyrights}

Copyright for this article is retained by the author(s), with first publication rights granted to the journal.

This is an open-access article distributed under the terms and conditions of the Creative Commons Attribution license (http://creativecommons.org/licenses/by/4.0/). 